\title{
Blockchain Based Smart Sukuk as Shariah Compliant Investment Avenues for Islamic Financial Institutions in Pakistan
}

\author{
Sarah Iftikhar* Irum Saba ${ }^{\dagger}$
}

\begin{abstract}
The biggest challenge for the Islamic banking industry in Pakistan is the scarcity of Shariahcompliant investment instruments and the absence of a lender of last resort (LOLR) facility for Islamic banks. Due to the problem of surplus liquidity, returns for Islamic banks in Pakistan are lower as compared to the conventional counterparts putting them at a competitive disadvantage with respect to their competitor conventional banks. Sukuk issuance is associated with a high cost of issuance and legal complexity, problems that could be solved by the application of blockchain technology. With the advent of cryptocurrency and developments around blockchain, technology experts, industry professionals along with Shariah scholars have been working to introduce FinTech in Shariah-compliant financing products and services. This research applies a qualitative approach. The study relies on primary data from interviews and secondary data from published sources, academic journals, government and private-sector reports, and public domain including newspaper articles, and websites. Interviews are conducted from blockchain technology experts along with banking $\mathcal{E}$ commerce industry professionals. This study highlights financial instability, lack of financial education and absence of political will being the main reasons for low Sukuk issuance in Pakistan. This study proposes a low-cost smart Sukuk structure to address the liquidity problem of the Islamic banking industry in Pakistan. It is found that smart Sukuk issuance and transaction fees are much lower than the current Sukuk issuances and are expected to be more secure and marketable internationally. Blockchain-based smart Sukuk are practicable to solve the problem of standardization and huge issuance and maintenance cost for the Sukuk industry. The proposed structure could be adopted by governments and organizations to issue Sukuk promising transparent, economical, efficient, and reliable business transactions for both parties.
\end{abstract}

Keywords: Blockchain, Cryptocurrency, FinTech, Shariah, Smart contracts, Sukuk.

\section{Introduction}

The Islamic banking industry in Pakistan constitutes around 15\% of total banking deposits in the country. In 2011, total outstanding Sukuk were around 56\% of Islamic banking deposits while in 2017 the percentage has dropped and outstanding Sukuk remains to around $22 \%$ of Islamic banking deposits. That is the major challenge that the Islamic banking industry in Pakistan is facing is the problem of excess liquidity against its growing deposit base. Sukuk has the potential to finance various infrastructure and development needs of the country's economy. In Pakistan, infrastructure development projects

\footnotetext{
${ }^{*}$ MS Scholar (Islamic Banking and Finance), Institute of Business Administration, Karachi, Pakistan.

Email: srhkshf@gmail.com

${ }^{\dagger}$ Assistant Professor, Department of Finance, Institute of Business Administration, Karachi, Pakistan.

E-mail: irumsaba@iba.edu.pk
} 
like China Pakistan Economic Corridor can be financed through the issuance of Sukuk. For sustainable growth of Islamic finance in the country, regular structures along with innovative structures need to be issued more frequently. Utilization of Pakistan Mercantile Exchange Commodity Trading Platform for introducing Shariah complaint alternatives for T-Bills would provide more exposure to Pakistan's Islamic finance industry (Alvi et al., 2019). PEC Chairman Engr. Jawed Salim Qureshi has proposed to issue Sukuk by launching Diamir-Bhasha Dam (DBD) Public Limited Company to finance the mega project (Dawn, 2018). It has also been proposed to finance the Naya Pakistan Housing Program (NPHP) by issuing Sukuk on the structure of Diminishing Musharakha (Awais \& Ali, 2019).

The total banking deposits Islamic banking industry in Pakistan has only one liquidity instrument to invest in i.e. government Ijarah Sukuk (GIS), worth PKR 368 billion held by Islamic banks. While for conventional banks two kinds of liquidity instruments namely T-Bills and PIBs amounting PKR 4.8 trillion and PKR 2.2 trillion respectively held by conventional banks as of June 2018, are available to meet their statutory liquidity requirement (SLR) set by State Bank of Pakistan (SBP). Before November 2016, both Islamic and Conventional banks were supposed to keep $19 \%$ of their total demand liabilities and time deposits in SLR eligible securities. Due to the maturity of Sukuk and the lack of Shariah-compliant instruments in the market for Islamic financial institutions, SBP revised the SLR requirement to $14 \%$ exclusively for Islamic banks. Instead of issuing new government-guaranteed SLR eligible instruments, SBP had given SLR eligible status to Sukuk issued by Public sector enterprises (PSEs) like Water and Power Development Authority (WAPDA) and Pakistan International Airlines (PIA). Sukuk are crucial, not only for Islamic banks but also for Takaful operators and Islamic Asset Management Companies requiring them for the creation of Islamic mutual funds. The government should allocate more assets parked in other ministries e.g. Railways for Sukuk issuances. Moreover, assets of the Public Development Sector Programme (PDSP) or Water and Power Development Authority (WAPDA) e.g. construction of dams and related infrastructure can be financed through Sukuk (S. Ahmed, 2018).

Sukuk has been issued by governments to finance the infrastructure projects but due to the high cost of issuance and legal complexity, it is limited to governments and huge organizations only. With abrupt growth in the global Sukuk issuances, there is a need to introduce new Sukuk structures and contracts based on the latest technology of blockchain to increase efficiency and reach the untapped segment of the market (Martin, 2018).

State Bank of Pakistan (SBP) has also identified liquidity management as a key challenge for Islamic Banking Industry as there is a scarcity of Shariah-compliant investment instruments and the absence of lender of last resort (LOLR) facility for Islamic banks. Due to the problem of surplus liquidity, returns for Islamic banks in Pakistan are lower as compared to conventional peers (Zaidi, 2018). 


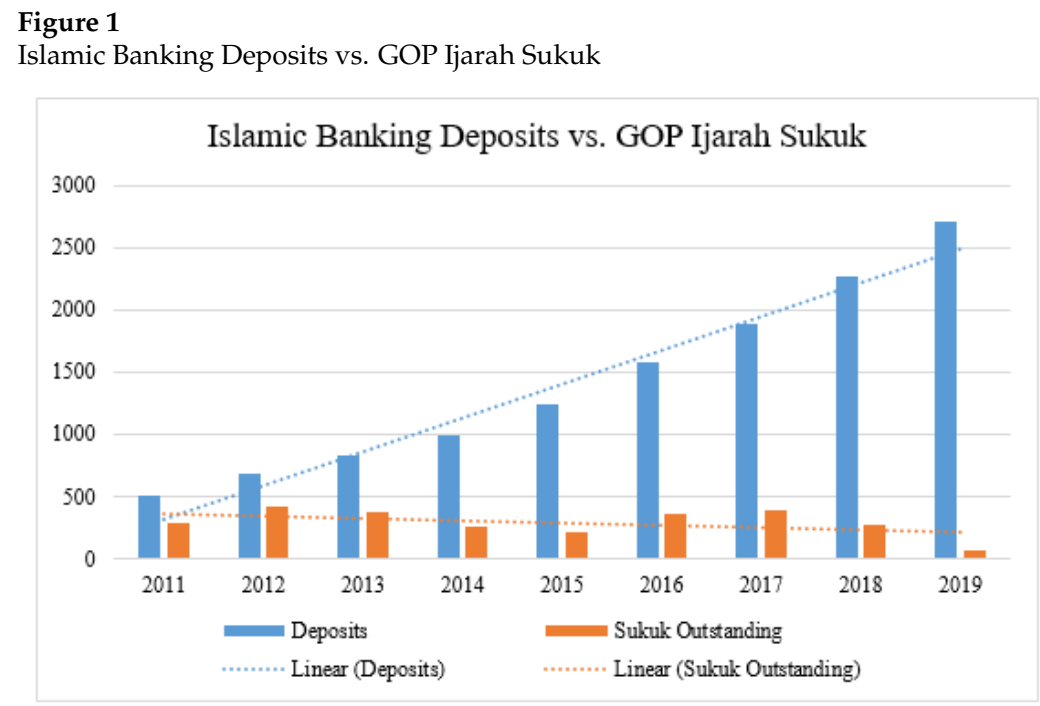

Digitalization, financial technology, and innovation are transforming different sectors of Islamic finance. Countries such as Malaysia, Bahrain and the UAE having sizeable Islamic financial systems are experimenting with FinTechs by creating regulatory sandboxes. Shariah scholars and researchers are evaluating blockchain-based cryptocurrencies and digital innovations in financial products for Shariah compliance. The finTech sector in the Islamic finance industry is expected to see digital transformation due to Shariahcompliant crowd-funding platforms and cryptocurrency startups soon (Mohamed \& Ali, 2019). With the advent of cryptocurrency and developments around blockchain, technology experts, industry professionals along with Shariah scholars have been working around the world to introduce FinTech in Shariah-compliant financing products and services mainly in Sukuk. Sukuk is a Shariah-compliant Islamic alternative to conventional bonds. It has been recognized as the most popular financial instrument of the Islamic finance industry with global issuance amounted to USD 123.15 billion in 2018 showing a modest growth of $+5 \%$ from USD 116.7 billion in 2017. Sukuk can be used to finance huge development and infrastructure projects by bringing consistent domestic and foreign investments (Alvi et al., 2019). This study focuses on the comparison of issuance and transaction costs of blockchain-based smart Sukuk with currently issued traditional Sukuk. In this study, the blockchain-based prototype system for smart Sukuk structure has been proposed that can be practically implemented to future Sukuk issuances.

Theoretically, this paper contributes to the growing literature on FinTech in Islamic finance and its application in real-world situations. Practically, the objective of this study is to urge the Islamic finance industry professionals to bring in innovative structures through technological developments to stay competitive in the market.

Blockchain-based smart Sukuk can be issued to enhance transparency, reduce cost and time, remove intermediaries, and eliminate the chances of fraud and speculation. The new low-cost technology encourages the involvement of small and medium firms and 
enterprises along with associations and projects with a social impact e.g. green Sukuk. Whereas conventional Sukuk issuances favor governments' organizations and agencies, huge companies, and banks because they are very costly in terms of issuances. Most of the academic research in the area of Islamic finance draws a comparison between Islamic banking and conventional banking while a few studies have examined the determinants of Sukuk issuance and Sukuk market development (Nagano, 2016). There is a dearth of research studies concerning the application of Blockchain technology in the issuance of Sukuk.

To stay competitive banks need to rely on new technological developments with early adoption to the changing customer needs. Banks can bring in product and service innovation through a change in traditional practice and process. Blockchain can be used to reduce the need for manual intervention for bookkeeping, reconciliation of transactions, and payments, eliminating paperwork by digitizing procedures through the successful execution of smart contracts. Hence payment, clearance, and settlement processes at banks and stock exchanges could be completely revolutionized by employing blockchain technology (Guo \& Liang, 2016).

This research applies a qualitative approach. The study relies on primary data from interviews and secondary data from published sources, academic journals, government and private-sector reports, and public domain including newspaper articles, and websites.

\section{Literature Review}

Distributed ledger technology (DLT) such as blockchain can transform traditional operating models of the financial sector in terms of information and communication (Herian, 2018). In a blockchain, transaction data is stored in blocks that are linked together to form a chain of blocks hence called blockchain (Gupta, 2017). Virtual Currency is a digital representation of value that is neither issued by the central bank nor attached to any fiat currency but is accepted as a means of payment by individuals or organizations and can be stored, transferred, or traded electronically. The first application of blockchain was the digital currency called bitcoin. Bitcoin emerged as a peer to peer electronic cash system in 2008 (Nakamoto, 2008) dominates the cryptocurrencies market in terms of market capitalization by $53.7 \%$. Like bitcoin, another application of blockchain is a smart contract that is a complex software program that is automatically executed upon fulfillment of a contractual obligation or predetermined condition already stipulated or programmed in the contract. Smart contracts can be customized having necessary clauses, terms and conditions programmed according to the nature of the contract. When parties to contract reach on an agreement, they deploy a cryptographically signed and time-stamped smart contract in a distributed ledger or blockchain. Upon fulfillment of a particular condition, the contract is automatically triggered. With the least chances of error, fraud, or delay, blockchain-based smart contracts can make business operations more economical, efficient and reliable (Mohamed \& Ali, 2019).

The current transaction system faces inefficiencies and limitations due to a long time taken between transaction and settlement, acceptability of cash (currency notes) for lo- 
cal transactions, presence of intermediaries, cyber-attacks, frauds, and mistakes, timeconsuming paperwork and inaccessibility to the formal banking network. In a blockchain, transaction settlement is faster because it does not require approval or verification for complex and multi-party interactions by a central authority. Blockchain technology reduces expenses because of the reduction of intermediaries and the elimination of duplication efforts as a result of accessibility to the shared ledger. They offer tighter security on a public network and a permissioned network is accessible to members only. Through enhanced privacy feature in permissioned blockchains, allows participants with IDs and permissions to view the ledger. Special viewers such as auditors or regulators can be given temporary access if they need to view a particular transaction in detail. The ability to audit and monitor transactions from a single source of truth i.e. is the shared ledger is improved along with increased operational efficiency in terms of speed and documentation (Gupta, 2017).

According to Delloite 2018 Global Blockchain Survey, the most important advantage of blockchain over existing systems is greater speed. Companies are interested in disrupting the blockchain's potential for real-time information exchange capabilities to speed up business processes and gain operational efficiencies. Blockchain can be used to simplify these complex contracts by introducing peer-to-peer networks between contracting parties, elimination of intermediaries (e.g. agents, brokers, and trusted third parties) thus minimizing operating fee and maintenance cost and guaranteeing secure transaction handling through the use of cryptography which makes a smart contract on the blockchain, difficult to hack (Gupta, 2017). The Digital revolution has started to revolutionize the Islamic banking industry with the launch of several digital banks without any physical presence.

Costs of issuing Sukuk are considerably higher than the costs of issuing conventional bonds due to lower liquidity and marketability that results in investors expecting to be compensated with a higher yield. The Sukuk market has not realized its potential due to a lack of standardization in documentation and Shariah interpretation related to Sukuk structures. Due to a lack of standardization in the Sukuk market, it remains uncertain with high issuance and transaction costs. Accounting and Auditing Organization for Islamic Institutions (AAOIFI), Islamic Financial Services Board (IFSB) and International Islamic Financial Market (IIFM) have been putting collective efforts for standardization of regulation around the Islamic finance industry (products and procedures). Standardization in terms of Sukuk documentation and Shariah interpretation can help decrease transaction cost and issuance cost, encourage Sukuk issuances and can bring diversity in Sukuk structures. It can help provide greater price transparency and liquidity to the primary and secondary Sukuk market by increasing tradability and trust among the industry participants. Sukuk issuance is perceived as a complex, time-consuming and expensive process as compared to the issuance of conventional bonds (Alvi et al., 2019; Damak, 2018). In this regard, it can be said that standardized documentation would reduce the cost of evaluation and negotiation of documents, lower issuance costs and saves time (Ulusoy \& Mehmet, 2018). Smart Sukuk can standardize and automate the accounting, legal and overhead payments of conventional Sukuk offering backed by the regulator or legislative body of the issuing country. 
As compared to conventional bonds, the cost of issuing Sukuk are expected to be higher because they involve several additional procedures like approval from Shariah Board and underwriting fee along with take-up commission that issuers pay to the trustee investment bank and these fees are uncompetitive due to imperfect competition. This fixed cost initially incurred by the issuer prevents small firms to tap the Sukuk market (Nagano, 2016).

Ratings by the third-party credit rating agencies also contribute towards the appropriate pricing of the Sukuk instrument through benchmarking where the issuer's financing cost will be lower if Sukuk is rated higher. The better a Sukuk is rated, the lower will be the coupon or profit rate need to be paid by the issuer hence incurring lower funding costs. In the absence of credit analysis by a credit rating agency, investors perceive instruments to be of low credit quality. Investors demand a higher risk premium for unrated corporate Sukuk to compensate for the potential default risk. Hence the funding cost will be higher (Alvi et al., 2019). On the other hand, credit rating agencies charge huge fees making Sukuk issuances expensive for the issuer. This makes issuers reluctant from getting their instruments rated from well recognized global credit rating agencies. Due to the complex structure of Sukuk, investors demand rated Sukuk because it enables them to price the instrument better and gives them the confidence to invest and trade in Sukuk (Ulusoy \& Mehmet, 2018). Since major rating agencies having expertise in rating both Sukuk and conventional bonds charge a high fee for their credible services, these instruments remain too expensive for corporate issuers that are focused on domestic issuances only.

The taxation system in most is the countries is not designed according to Islamic banking products results in disadvantages for the institutions offering Shariah-compliant services. Generally, interest payments are tax-deductible while profits are taxable resulting in profit sharing products (like musharakhah and mudarbahah Sukuk) unattractive for investors. On the other hand, services offered by the conventional counterparts stay attractive due to the tax benefit the investor gets. Due to parallel contracts and complicated processes, additional sales tax and stamp duties have to be paid in a murabahah and ijarah transaction respectively. There is a dire need to improve the taxation and regulatory framework in the country for providing level playing field between Islamic and Conventional institutions for the promotion of Islamic finance. In 2016, the Federal Board of Revenue in Pakistan granted tax neutrality to Sukuk transactions to develop the country's Islamic finance industry. Due to multiple asset transfers in an asset-backed Sukuk transaction, issuers of the securities have to pay excessive tax as the Sukuk regulations classified underlying assets in Sukuk transactions as fixed assets. The reforms provided exemptions to tax on rental income earned by the SPV and taxable gains and withholding taxes linked to multiple transfers of the underlying asset (Vizcaino \& Torchia, 2016).

Islamic financial institutions can reduce the cost of overall operations through the introduction of technology. Any transaction initiated using the blockchain platform would be irreversible, tamper-proof, accessible from any system and immutable. It gives credibility to the Islamic financial institution and the transaction for being truly shariah-compliant, builds trust among the transacting parties, and promotes the growth of Islamic economy and finance. Trust issues due to lack of traceability would go since the history of the 
transaction and instruments will become available and visible to the transacting parties. Sukuk issuance is complex in terms of structure and legal form as it involves multiparty contracts, data inconsistencies, and delays due to reconciliation, clearing and settlement along with chances of errors.

Since Shariah law is interpreted differently in different countries in terms of regulations and structures of Sukuk, creation of central Shariah Advisory Board in a country for investor guidance on Shariah-compliant products and bringing uniformity in Sukuk standards and regulations can help reduce transaction and issuance costs, improve liquidity along with the development of the secondary market and provide greater price transparency to market participants.

Due to a lack of transparency in the whole process, investors are not sure whether they are getting the fair share of profit or their proceeds are being invested in Shariahcompliant avenues since the actual performance of the underlying asset or project couldn't be monitored. Because of irregular legal and accounting infrastructure in some countries, investors cannot verify the accuracy of data available against a particular Sukuk transaction. By enabling traceability of funds through the application of blockchain investor confidence in Islamic financial instruments could be improved.

Blockchain has been worked on by many financial institutions to improve the existing financial system making banks better by reducing cost, making them more secure and reliable (Batlin, Jaffrey, Murphy, Przewloka, \& Williams, 2016). The study focus on risks and costs specifically associated with traditional Sukuk transaction and compared these with the benefits smart contracts and blockchain are going to offer in the future. In Islamic banks, contracts are relatively complex since a single Shariah-compliant product needs multiple independent and non-contingent agreements including partnership agreement, agency agreement, and profit and loss sharing agreement to be executed. Hence blockchain-based smart contracts are most relevant to the Shariah-compliant products (Krishnakumar, 2018). While in a conventional bank, contracts are simple and a single contract of loan where interest can be charged upon can fulfill the purpose (Z. Ahmed, 2016). Due to complex Sukuk structures, a high advisory fee is charged from the issuer during the issuance process, and on the other hand high due diligence costs are incurred by the investors to review all the related documents. Since an Islamic Financing deal involves two to three independent agreements in a single contract it involved higher legal and administrative costs as compared to conventional counterparts. Due to multiple contracts in Islamic banking, users and investors are subject to costly transactions. A digitally handled smart contract has all the terms and conditions of the agreement built in the code ideally reduces legal and administrative difficulties. These are secure, immutable, and verifiable hence eliminates operational and counterparty risks (Sehgal, 2018).

\section{Research Methodology}

This research applies a qualitative approach. Data is mainly collected from secondary sources including annual reports of financial institutions, regulatory authorities' statistical databases, financial stability reports, official press releases, newspaper articles, opinions 
of professionals \& practitioners and speeches, etc. In-depth interviews using purposive sampling are also conducted in this research to seek the personal standpoint of the interviewee. Non-probabilistic samples are often used for field-oriented researches that do not require statistical inference. This research aims to gather knowledge from individuals having particular expertise hence to select the interviewee, expert sampling is done while focusing on individual characteristics of the population that will be able to meet the research demands.

\section{Blockchain based Low Cost Sukuk Structure}

Application of distributed ledger technology calls for the integration of all the market participants on blockchain for optimized results. All the financial, regulatory, and support functions should be on the permissioned blockchain-based server. Permission refers to the authority to verify and on a permissionless or public network, anyone can join the system to be a verifier without acquiring any earlier consent to perform such system assignments on the network. While on permissioned blockchains, there are trusted parties that carry out verification, and participants are added to the network with the consensus of the current members or central authority. This setting resembles the traditional finance system that follows Know Your Business (KYB) or Know Your Client (KYC) procedures to allow users to perform particular transaction or entry on the network.

\section{Transaction Structure of proposed Blockchain based Smart Ijarah Sukuk}

The transaction structure of proposed smart Sukuk is described in comparison with the transaction structure of GOP domestic ljarah Sukuk (M2) for clarity and understanding of the readers. The important documents required to be signed and executed during a Sukuk transaction making it difficult from an operational perspective are as follows:

\begin{tabular}{cll}
$\begin{array}{l}\text { Table } \mathbf{1} \\
\text { Documents crucial to Sukuk Issuance }\end{array}$ & \\
\hline Sr. No. & $\begin{array}{c}\text { Important Documents } \\
\text { (Pertains to issuance of Sukuk) }\end{array}$ & \multicolumn{1}{c}{$\begin{array}{c}\text { Signatories } \\
\text { (Parties to contract) }\end{array}$} \\
\hline 1 & Sukuk Subscription Undertaking & $\begin{array}{l}\text { Investors } \\
\text { SPV and Issuer }\end{array}$ \\
3 & Sukuk Issuance Undertaking & SPV and Issuer \\
4 & Purchase Agreement & SPV and some other agent \\
5 & Agency Agreement & SPV and some other agent \\
6 & Ijarah Agreement & SPV and Issuer \\
7 & Service Agency Agreement & SPV and Issuer \\
8 & Purchase Undertaking & Issuer \\
9 & Cost Undertaking & Issuer \\
\hline Source: Author's Illustration &
\end{tabular}

All these documents will be programmed to form individual and independent programs in a smart contract that will be simultaneously self-executed one after the other upon fulfillment of a specific condition that in the taken case is payment and due date.

In pre-screening criteria/tests, it would be mandatory for the participant to have the price of the intended buy already on the network account. Otherwise, investors will not 
be able to enter the blockchain network. Similarly for an issuer, asset, its possession, and legal documentation has to be available on the system for subsequent transfer of the asset to the SPV or investor directly. According to the proposed model, each sak (certificate) will represent undivided ownership of investors in the asset hence the asset is transferred to SPV instead of individual investors.

\section{Transaction Structure of Proposed Blockchain based Smart Ijarah Sukuk}

State Bank of Pakistan (SBP) will conduct a prescreening test for the investors laying terms and conditions need to be fulfilled to subscribe for the Sukuk issuance. Investors passing the prescreening criteria (electronically) will be made part of the consortium blockchain network. On the same blockchain network, investors will execute Sukuk Subscription Undertaking in favor of the SPV. Sukuk Subscription Undertaking is programmed to make a smart contract which will be automatically executed upon entering into the network. Sukuk Issuance Undertaking will also be automatically executed on the due date. On the due date, the blockchain network account of the investor will be debited from the subscription amount and the proceeds will be used by the SPV to purchase assets as an agent on behalf of the investors. On behalf of investors, SPV will electronically that too on the blockchain network, execute Purchase Agreement with GOP (or any other issuer) for transfer of ownership of assets against the issuance of Sukuk equivalent to the amount of Sukuk subscription paid by the investors. Proper offer and acceptance between SPV and issuer will be affected through time-stamped blockchain-based smart contracts. SPV will transfer the subscription amount debited from the investors' account to the issuer account as the purchase price of the asset. The transfer of the asset (either partial, full, or in tranches) has to be reflected in the financial statements of the issuer that too should be accessible to the participants of the network. The transfer of ownership from the issuer to SPV will also take place on the blockchain network. Declaration of Trust will be executed in favor of investors to effect that SPV will hold the registered title in trust for the Investors. A smart contract will prove that the possession of assets is transferred to investors (SPV as an agent of investors). SPV will also confirm that all the risks and rewards associated with the underlying asset have been passed on to the investors. All these clauses will be programmed in a smart contract. To function at its maximum, blockchain calls for the integration of all the participants of Sukuk (i.e. regulators, issuers, government accounts, and banking channels) on a single network. We need to assume here that blockchain-based electronic contracts are recognized by law and have legal recourse. SPV will hold the registered title to the Trust Assets while other duties and powers could be delegated to other agents (should be on blockchain network) under the Declaration of Trust. An agency agreement already programmed in the mega smart contract can be executed between SPV and SBP's Banking Services Corporation or any other commercial bank that can act as paying agent, reference agent and registrar for the Investors. Ijarah Agreement will be executed between the issuer and SPV where the investors share in the asset will be leased to the issuer for a predetermined fixed period. All the terms and conditions will remain as it is and will be programmed as a separate smart contract. In the blockchain-based Service Agency Agreement, the issuer will be appointed as a service 
agent will undertake to provide service and maintenance of the asset during the lease period against a nominal fee. It will be already programmed in the smart contract that in case of default the issuer/ Guarantor / GOP will purchase the asset at the exercise price. Terms and conditions related to exercise prices are already stipulated in the purchase agreement. Cost undertaking binds the issuer to pay all the costs associated with the process of issuance. Periodic Rent on a predetermined rate of return will be credited to the investor account at regular intervals.

Figure 2

Periodic Lease Rental Payments to the Investors

Source: Author's Illustration

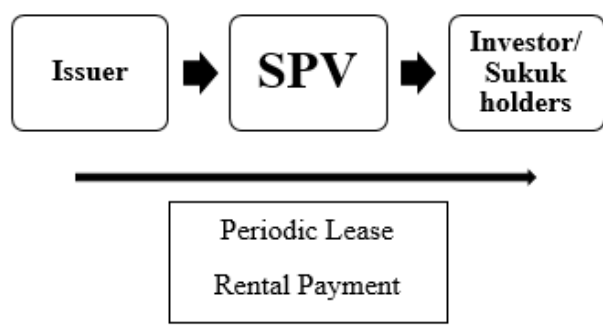

Upon maturity (maturity date), the issuer will make the final principle payment and sukuk certificates matures.

Figure 3

Principle Repayment at Maturity

Source: Author's Illustration

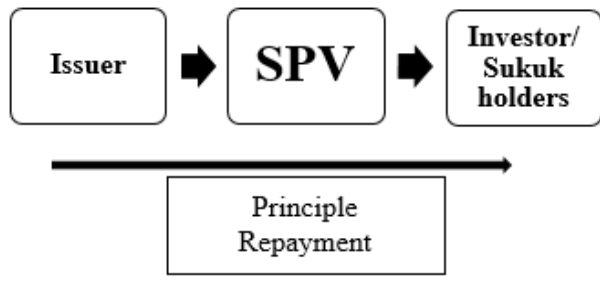

The main transaction is powered by blockchain based smart contract that transfers the ownership of the asset to the SPV or investors directly. It collects subscription amount from investors and make payment to the issuer on real time basis. The mechanics of the smart contract are presented in the figure below.

All the important individual contract documents will be programmed as smart contracts having a time stamp and electronic signatures of the participants. 
Figure 4

Ijarah Smart Sukuk Structure

Source: Author's Illustration

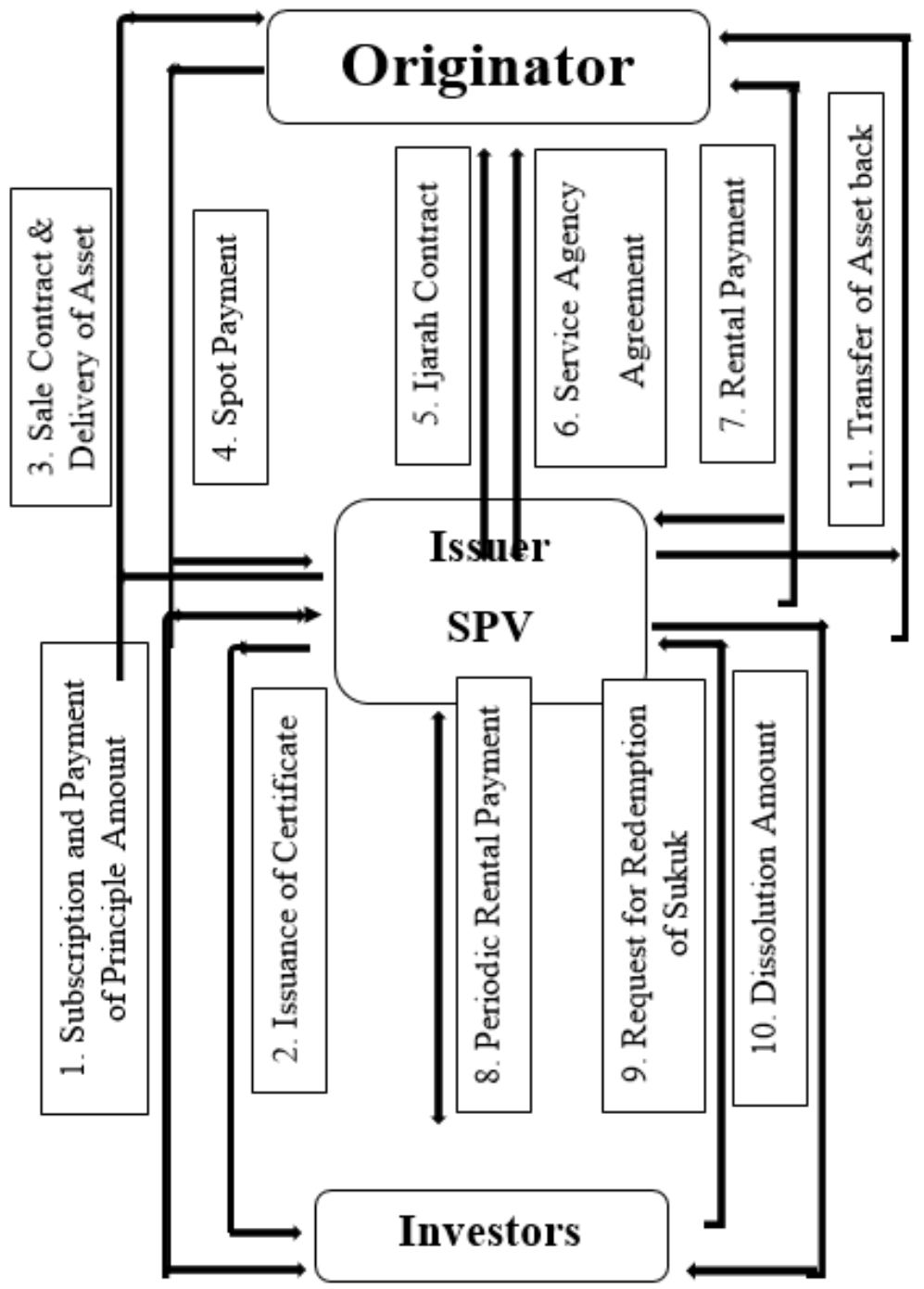


Figure 5

Process Flow of Blockchain based Smart Sukuk

Source: Author's Illustration

Starting Node
- History of the Asset, its ownership and registration with the legal
and regulatory body of the country (SECP in case of Pakistan).
Details of the asset regarding its presence, traceability, location,
market value is automated and accessible by the participants.


Figure 6

Mechanics of a Smart Contract

Source: Author's Illustration (Marc, 2017)

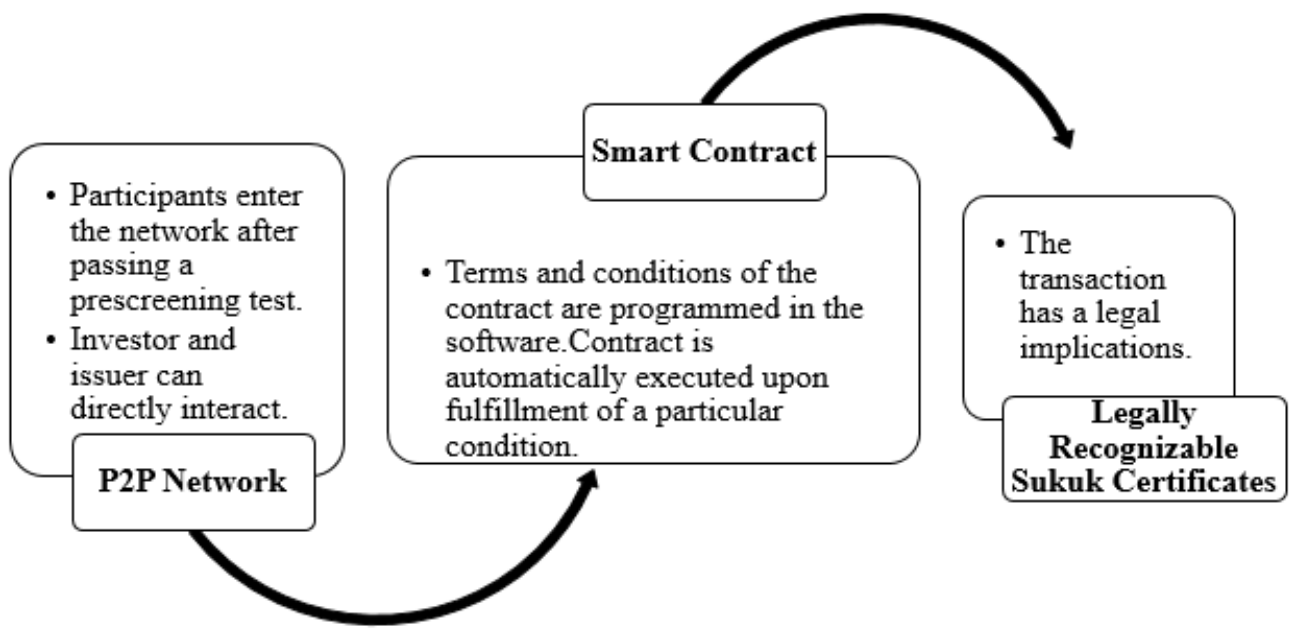

\section{Conclusion}

The proposed Sukuk structure is less costly as compared to the traditional Sukuk issued in Pakistan that involves numerous intermediaries and hefty documentation making the overall issuance transaction time consuming and expensive. Through the proposed automated smart contract, Sukuk could be issued without incurring much cost and effort hence supporting the economy and Islamic banking industry on Pakistan.

The most important challenge for the Islamic banking industry in Pakistan has excess liquidity against the growing deposit base but lacks adequate Shariah-compliant avenues to invest available customers' fund pool to generate competitive returns with respect to conventional counterparts. Due to a lack of Shariah-compliant liquidity management instruments or equivalent government securities and money market instruments, the Islamic banks in the country are at a competitive disadvantage with respect to their competitor conventional banks. Instead of seeking finance from external sources, the Government of Pakistan should issue new Sukuk in the market to generate financing internally from Islamic Banks (Usmani, 2018).

The main objective of blockchain technology is to reduce intermediaries and the overall cost of a transaction without compromising the credibility of structures in terms of Shariah. The continuous development is changing the dynamics of the business, particularly, in the region of Fin-tech \& blockchain and the Sukuk market is destined to profit by these innovative progressions (Alvi et al., 2019). Costs of issuing Sukuk are considerably higher than the costs of issuing conventional bonds due to lower liquidity and marketability that results in investors expecting to be compensated with a higher yield. 
With Blockchain-based smart contracts, underlying assets in Islamic finance transactions could be tracked in real-time including replacement, removal, or alteration pertaining to that asset. Through traceability features, it could be ensured that the embedded asset is exclusively used for Islamic finance transactions minimizing the risk of default due to Shariah non-compliance. Shariah scholars and investors often question the opaqueness of the Sukuk issuance process and difficulty in tracking the underlying assets. The legal documents only mention terms and conditions related to the contract and contains clauses that limit investors' recourse in case of a total-loss event or in event of substitution or replacement of the asset. In case of replacement of underlying assets or early-dissolution of the security, the issuer is obliged to inform the investors through electronic or nonelectronic channels. Upon response to a certain percentage of investors, the decision is taken by the management making the process inefficient and opaque. Through smart contract protocols, Sukuk structures could be documented in a more transparent way as the technology will enable automatic execution of a contract as all the clauses (terms and conditions) of the contract are embedded in a programmed Sukuk contract. This would allow maintenance of a real-time register of Sukuk holders and would speed up the resolution of disputes preventing lengthy and uncertain legal proceedings. Blockchain technology can make information available to all the concerned parties including issuer investors and auditors, minimizing the risk of Shariah non-compliance. Information asymmetry and post-issuance compliance issues will be minimized as the data will be accessible to external Shariah auditors and would be easy to compile and reconcile. The same feature will help in early detection of any irregularity for example if any payment in an Ijarah structure is missed by the lessee, the absence of the block from the chain will reveal the default and corrective action can be taken more promptly.

\section{Limitations and Future Research Directions}

Detailed Ijarah Sukuk structure has been studied and compared in this research. However, if this technology is introduced in the system, Sukuk of small denominations by small corporations of multiple structures could be issued and subscribed by the general public through smartphone applications. Hence along with technological advancement, the goal of financial inclusion and equitable distribution of wealth could also be achieved. Making use of Digital Financial Services Framework, Sukuk structure could be launched where subscribers can subscribe for investment in Sukuk through their smartphones hence increasing financial inclusion.

On the basis of this work, smart contracts can be programmed for other Islamic finance products within a bank to eliminate paperwork and costs associated with excessive documentation and record-keeping. Other Islamic banking products could be studied for the application of distributed ledger technologies and programming could be done for the subsequent products. 


\section{References}

Ahmed, S. (2018). Why Islamic banks are getting riskier. Retrieved from https://www .dawn.com/news/1439043

Ahmed, Z. (2016). Blockchain in Islamic banking - opportunities aplenty. Retrieved from http://thefintechtimes.com/blockchain-islamic-banking -opportunities-aplenty/

Alvi, I. A., Rufai, A., Dadabhoy, I., Naseer, B., U Mand Naseer, Fouad, T., \& Sayyed, Z. (2019). IIFM Sukuk Report. Manama: International Islamic Financial Market. Retrieved from https: / / www. dawn.com/news/1439043

Awais, A., \& Ali, M. A. (2019). Sukuk can finance naya Pakistan housing programme. Retrieved from https://www.dawn.com/news/1457309/sukuk-can-finance -naya-pakistan-housing-programme

Batlin, A., Jaffrey, H., Murphy, C., Przewloka, A., \& Williams, S. (2016). Building the trust engine. How the blockchain could transform finance (and the world). UBS AG.

Damak, M. (2018). Islamic finance to still grow in 2016 but with a sag. Islamic Finance News.

Dawn. (2018). Diamer-bhasha dam sukuk proposed. Retrieved from https: //www. dawn . com/news/1438504

Guo, Y., \& Liang, C. (2016). Blockchain application and outlook in the banking industry. Financial Innovation, 2(1), 1-12.

Gupta, M. (2017). Blockchain for dummies. John Wiley \& Sons.

Herian, R. (2018). Taking blockchain seriously. Law and Critique, 29(2), 163-171.

Krishnakumar, A. (2018). Is blockchain relevant for shariah compliant banking products? Retrieved from https://dailyfintech.com/2018/03/23/the-blockchain -case-within-islamic-fintech/

Martin, M. (2018). Islamic finance upgraded: Smarter sukuk using blockchain. Retrieved from https://blossomfinance.com/press/islamic-finance-upgraded -smarter-sukuk-using-blockchain

Mohamed, H., \& Ali, H. (2019). Blockchain, fintech and Islamic finance. Walter de Gruyter Inc, $10,9781547400966$.

Nagano, M. (2016). Who issues sukuk and when?: An analysis of the determinants of islamic bond issuance. Review of Financial Economics, 31, 45-55.

Nakamoto, S. (2008). A peer-to-peer electronic cash system. Retrieved from https:// bitcoin.org/bitcoin.pdf

Sehgal, V. (2018). Islamic banking and blockchain technology: When the two paths meet. Retrieved from https://4rev.com/islamic-banking-and -blockchain-technology-when-the-two-paths-meet/

Ulusoy, A., \& Mehmet, E. (2018). Secondary market of sukuk: An overview. Uluslararası İslam Ekonomisi ve Finansı Araştırmaları Dergisi, 4(2), 17-32.

Usmani, F. U. (2018). Islamic banking. Retrieved from https://fp.brecorder.com/ 2018/08/20180812398884/

Vizcaino, B., \& Torchia, A. (2016). Pakistan grants tax neutrality for sukuk deals. Retrieved from https://www.reuters.com/article/us-pakistan-sukuk -idUSKCN11A07P 
Zaidi, E. (2018). SBP to buy Rs111 billion worth Ijara sukuk. Retrieved from https://www.thenews.com.pk/print/405487-sbp-to-buy-rs111 -billion-worth-ijara-sukuk 